\title{
Micropalaeontological dating of the Prémontré mammal fauna (MP10, Prémontré Sands, EECO, early late Ypresian, Paris Basin)
}

\author{
ETIENNE STEURBAUT ${ }^{1 *}$, JAN DE CONINCK ${ }^{2} \&$ STEFAAN VAN SIMAEYS ${ }^{3}$
}

${ }^{1}$ Royal Belgian Institute of Natural Sciences (RBINS), OD Earth and History of Life, Vautierstraat 29, 1000 Brussels \& KU Leuven, Belgium; etienne.steurbaut@naturalsciences.be.

${ }^{2}$ Universiteit Gent, Research Unit Palaeontology - WE13, Krijgslaan 281/S8, B-9000 Gent, Belgium.

${ }^{3}$ ExxonMobil Upstream Research Company, 22777 Springwoods Village Pkwy, Houston, TX 77389, Texas, US; svansimaeys@ yahoo.com.

* corresponding author.

ABSTRACT. At their type locality the Prémontré Sands contain fairly well-diversified organic-walled microfossil assemblages attributable to the lower part of dinoflagellate cyst Zone D9 and indicating a transition from an estuarine to a lagoonal depositional regime, up-section as well as laterally. Identical assemblages have been recorded in the inner to mid-neritic Merelbeke Clay Member in Belgium, allowing the Prémontré Sands to be positioned within lower NP13 and early Chron C22r. The deposition of the MP10 Prémontré mammal fauna is estimated to postdate the onset of both NP13 and Chron C22r, which are nearly coincident, by about 200 to $300 \mathrm{kyr}$. The biostratigraphic dating refers this deposit to the early late Ypresian and to the final phase of the Early Eocene Climatic Optimum (EECO) at about 50.4 to 50.3 million years ago. The Prémontré Sands, as well as their distal equivalent the Merelbeke Clay Member, were deposited following a major sea-level rise, the highest of the late Ypresian in the southern North Sea Basin s.l. (including the Paris Basin). They are separated from the overlying "Glauconie grossière" (zone NP14; middle part of zone D9) by a hiatus of approximately 2.5 myr.

KEYWORDS: Organic-walled microfossils, calcareous nannofossils, Prémontré Sands, MP10, palaeoenvironment, Paris Basin, EECO, early late Ypresian

\section{Introduction}

As a result of long-term and intensive fossil collecting (see Russell, 1964; Rat, 1965 and Louis, 1996 for overviews) the Paris Basin has become one of the hot spots in the reconstruction of Paleogene continental mammal evolution, and the home of about two thirds of the reference levels of the European Paleogene mammalian biochronological scale (Schmidt-Kittler, 1987). This particular status is also due to its position along the eastern edge of the Atlantic Ocean, allowing marine and continental strata to meet, and its particular tectonic history. Large parts of the Paris Basin were affected by strong subsidence generating relatively complete and rather thick sedimentary successions, marine as well as continental (Gély \& Lorenz, 1991; Duprat, 1997a).

In spring 1980, an almost $20 \mathrm{~m}$ thick succession of essentially sandy sediments has been exposed during works inside the Psychiatric Hospital of Prémontré. This hospital was built on the ruins of the medieval Prémontré Abbey, about

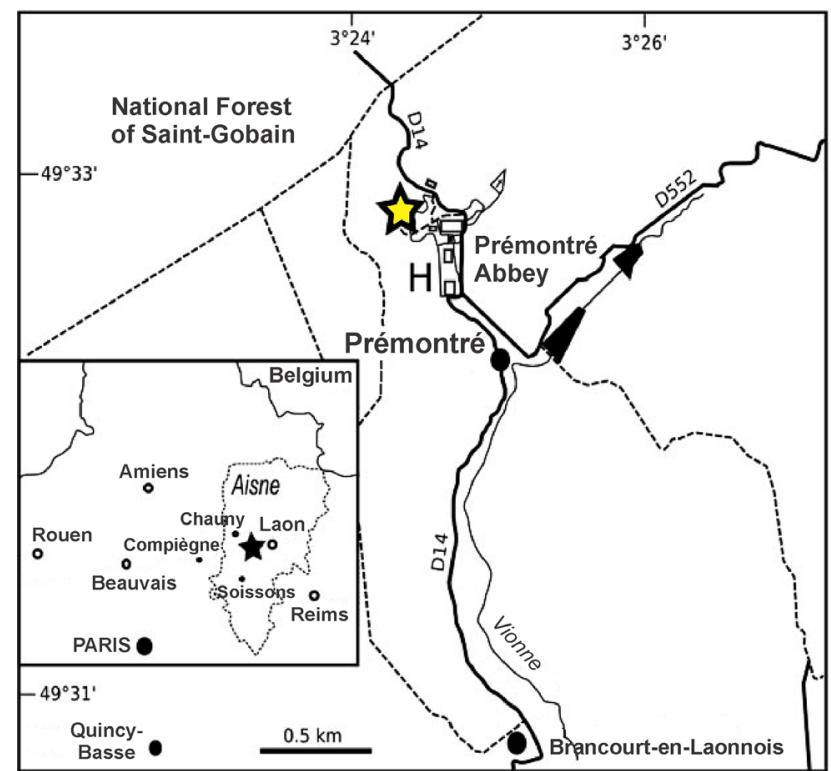

Figure 1. Location of the Prémontré outcrop section (after Adnet \& Cappetta, 2008)
$15 \mathrm{~km}$ west of the city of Laon, in the northeast of the Paris Basin (Fig. 1). Since its discovery scientists have been mainly focussing on the lower part of the Prémontre section (unit 2 of Dégremont et al., 1985, for which these authors introduced the term Prémontré Sands), which yielded an intriguing mix of continental, terrestrial as well as aquatic, and marine fossils. A preliminary list of these taxa was given by Dégremont et al. (1985), mentioning plant fragments (seeds, wood, leaf imprints), a few moulds of freshwater and brackish-water molluscs, freshwater and marine bonyfish, fragments of frogs, turtles, crocodiles, a few bird bones and a quite diverse fauna of lizards, subsequently reviewed by Augé et al. (1997) and Augé (2003). The rich and varied fauna of sharks and rays was reinvestigated by Cappetta (1992) and Adnet \& Cappetta (2008), increasing the number of taxa from 19 to 32. Although unique for its exceptional biodiversity, the Prémontré site is above all famous for its abundant and highly diversified mammal fauna, assigned to reference level MP10 (Dégremont et al., 1985; Schmidt-Kittler, 1987; Godinot, 1987; Godinot et al., 1992; Louis, 1996; Duprat, 1997b; Escarguel, 1999; Smith, 2001). Because of its abundance and diversity, this mammal fauna, as well as the other vertebrate groups, have been cited or briefly discussed in many other papers dealing with palaeontology (e. g. Blanc-Louvel, 1986; Hooker, 1996; Marivaux et al., 2004) and in major reference works on the evolution of life on earth (e.g. Russell, 2009; Wallach et al., 2014).

Besides its phylogenetic relationships, the age and depositional environment of the Prémontré vertebrate fauna have also been a major topic of discussion. A late Cuisian age was tentatively suggested by Dégremont et al. (1985), although without further precision. This assumption was merely based on its mammal content (intermediate between the fauna of the Cuisian "Sables à Unios et Térédines", e.g. Saint-Agnan and the Lutetian faunas, e.g. Bouxwiller) and its stratigraphic position below the "Glauconie grossière". The latter consists of a series of alternating coarse-grained and fine-grained glauconitic sands rich in calcareous concretion levels, representing the lower part of the historical Lutetian stratotype (Blondeau, 1981; Merle, 2008; Molina et al., 2011). The stratigraphic position of the Prémontré mammal site has been narrowed down through the years using a wide variety of criteria. It was linked with the calcareous nannofossil zonation (NP Zones) of Martini (1971), although 
always indirectly and without solid arguments. A tentative attribution to zone NP13 was suggested by Hooker (1996). This was based on the occurrences of the MP10 marker taxa Ailuravus michauxi, Nannopithex zuccolae and Pantrogna sp. (subsequently called P. marandati by Escarguel, 1999) in the upper Wittering Formation of southern England, assumed to belong to NP13, and which were also recorded in the Prémontré Sands (Godinot et al., 1992; Escarguel, 1999). Escarguel (1999) and Adnet \& Cappetta (2008) assigned the Prémontré fossil level and its MP10 mammal fauna to NP12, on the one hand because of its position within the "Sables de Glennes" (included in the Laon Formation), and on the other hand because of its shark fauna and its relationship with that of the Egemkapel Clay in the Belgian Basin, which belongs to the lower part of upper NP12 (subzone VIb of Steurbaut, 1998). However, the few mammal finds recently collected at the base of this Egemkapel Clay seem to contradict this correlation, clearly pointing to reference level MP8+9, instead of MP10 (Smith \& Smith, 2013).

The present study aims for the first time at recalibrating the age of the Prémontré site through an integrated investigation of its dinoflagellate cyst and calcareous nannofossil assemblages, Ypresian as well as Lutetian, and through direct micropalaeontological correlation with the well-dated upper Ypresian deposits of Belgium. The latter represents the most complete and most fully marine upper Ypresian succession of the southern North Sea Basin s.l. (including Belgium, the London-Hampshire Basin and the Paris Basin). This integrated approach will lead to a better understanding of the stratigraphy of the upper Ypresian (upper Cuisian auct.) in the Paris Basin and will contribute in accurate plotting of the successive European Paleogene mammal sites and reference levels onto the geological time scale.

\section{Geographic and geological setting}

The majority of the fossil material from Prémontré comes from a 4 to $5 \mathrm{~m}$ thick fossiliferous level, termed Prémontré Sands or unit 2 by Dégremont et al. (1985), which was temporarily exposed on the left of the "Atelier" building in the W corner of the Prémontré site (section 1: GPS-coordinates: $49^{\circ} 32^{\prime} 48.26^{\prime \prime} \mathrm{N}-3^{\circ} 24^{\prime} 21.52^{\prime \prime} \mathrm{E}, \mathrm{Fig}$. 1). It consists of yellowish green bioturbated, almost completely decalcified sand $\left(\mathrm{CaCO}_{3}\right.$ $<1 \%$, Dégremont et al., 1985, tab. 1), with coarse quartz grains and flint fragments in its basal part and occasionally higher up. It rests on homogenous decalcified micaceous yellow fine sands, tentatively attributed to the Pierrefonds Sands, and is unconformably (non-depositional surface with deep burrows) overlain by several meters of glauconiterich calcareous coarse sands, glauconitic bioturbated fine sands and obliquely stratified fine sands, representing the "Glauconie grossière" (Fig. 2). The overlying sediments, a series of fossiliferous limestone layers, separated by sands with limestone concretions, have been recorded higher up in the escarpment, cutting through what is locally called the Saint-Gobain Massif (Leriche, 1937; Gély, 2009). The highly glauconitic sands and overlying limestone levels represent the lower part of the historical Lutetian stratotype, as seen in many outcrops in the Paris Basin (Leriche, 1937, Blondeau, 1981; Steurbaut, 1988; Gély, 1996; Merle, 2008).

About $30 \mathrm{~m}$ laterally (section 2 of Dégremont et al., 1985) the vertebrate-rich unit 2 passes into fossiliferous crossbedded sands, with several thin marly, clayey and more or less lignitic interbeds. Its facies characteristics are comparable with those of the Glennes Sands (Leriche, 1937), exposed in the Glennes-Fismes area, $30 \mathrm{~km}$ southeast of Prémontré, which are considered to be a lateral equivalent of the Laon Clays (Leriche, 1937). However, in their type-locality these cross-bedded Glennes Sands are leached and do not contain fossils, except some fragments of silicified tree trunks (Leriche, 1912, 1937). They probably represent the fluviatile upstream equivalent of the Prémontré Sands. A slightly different section, with $1 \mathrm{~m}$ of stiff clay, assigned to the Laon Clay, and resting on $70 \mathrm{~cm}$ of glauconitic sand, has been observed in the

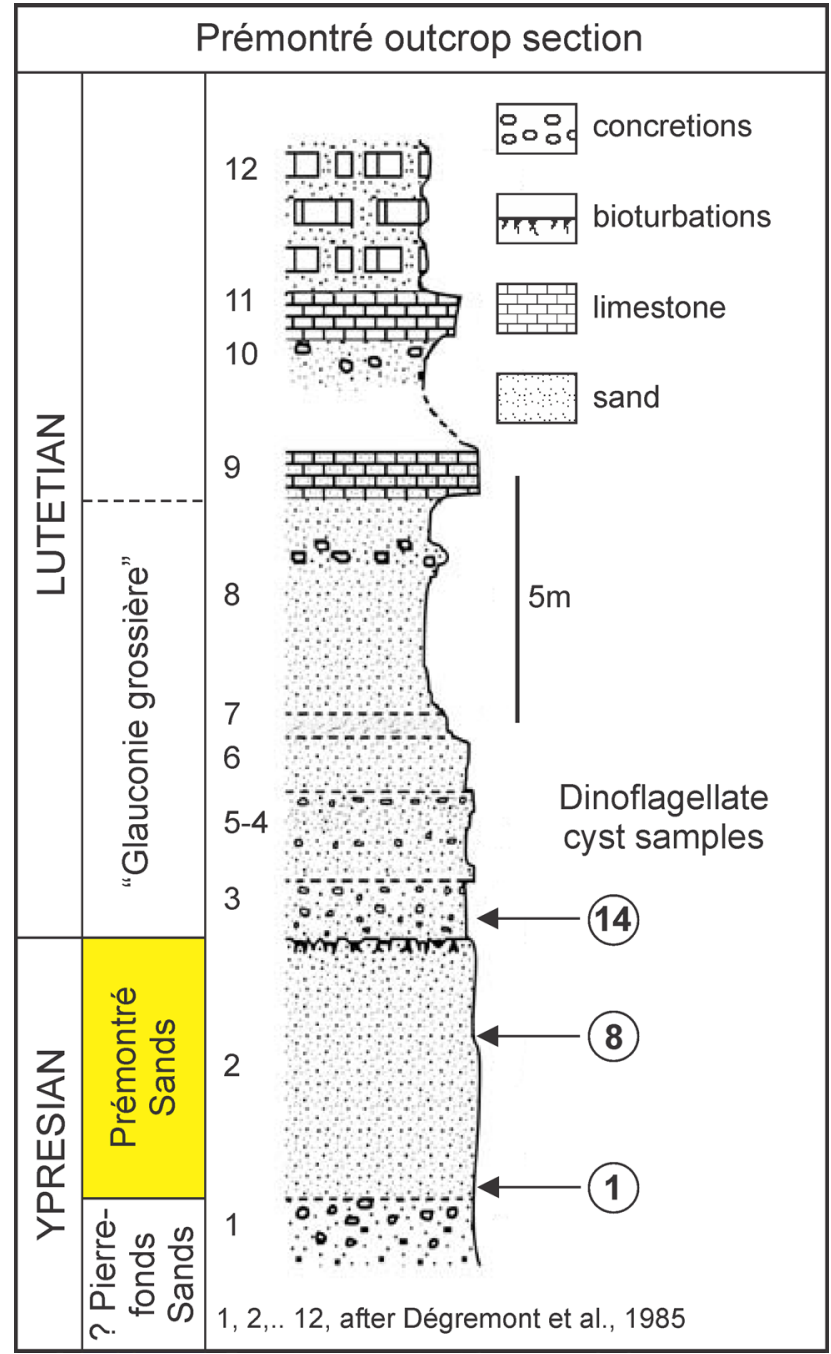

Figure 2. Stratigraphic interpretation of the Prémontré outcrop section, with location of the samples studied here (lithology after Adnet \& Cappetta, 2008, slightly modified).

1970s, 300 m northeast of the Prémontré-Atelier site, at the right side of the road running along the Prémontré Hospital wall towards Septvaux (known as the Prémontré sandpit, Delattre et al., 1973).

\section{Sampling and methods}

The calcareous nannofossil analysis is based on a series of 18 samples collected by H. Cappetta in the early 1990s, the lowermost 12 of which were taken in the Prémontré Sands (unit 2), at approximately $0.3 \mathrm{~m}$ spaced intervals, and the uppermost 6 in the lowermost $1.5 \mathrm{~m}$ of the "Glauconie grossière". Sample preparations and nannofossil investigation were carried out using standard procedures as described in Steurbaut \& King (1994). About two square centimeters of glass-slide have been examined for each sample analysed, using a Zeiss light microscope at $1000 \mathrm{x}$ or $1250 \mathrm{x}$ magnification. Martini's (1971) standard Paleogene calcareous nannofossil zonation (traditionally abbreviated to NP zones) and the high-resolution high latitude zonation of Steurbaut (1998) are applied here. The taxonomy is essentially from Perch-Nielsen (1985), taking into account subsequent modifications by Young \& Bown (1997), Aubry \& Bord (2009) and Steurbaut (2011). The nannofossil samples, residues and slides are stored in the collections of the RBINS (Brussels, Belgium).

Samples 1 and 8 from the base and the middle of the Prémontré Sands respectively, and sample 14, just above the base of the "Glauconie grossière", have been examined for dinoflagellate cysts and other organic-walled microfossils (Fig. 2), following processing techniques described in De Coninck (1977). The dinoflagellate cyst zonation (D-zonation) 
is that of Costa \& Manum (1988), taking into account the modifications of Köthe (2012). The samples, residues and slides are kept at the Department of Geology and Soil Science of the Universiteit Gent.

\section{Results}

\subsection{Calcareous nannofossil diversity and biozonation}

The Prémontré Sands are almost totally decalcified $\left(\mathrm{CaCO}_{3}\right.$ $<1 \%$ ), and completely devoid of calcareous nannofossils.
The assemblages from the lower part of the "Glauconie grossière" (samples 15 to 17 ) are moderately well preserved and moderately diverse. They are dominated by medium-sized Noelaerhabdaceae taxa (Cyclicargolithus pseudogammation and Reticulofenestra dictyoda) and are marked by the presence of Discoaster sublodoensis, Discoaster nonaradiatus, Pemma spp., Birkelundia sp. and Blackites creber. Blackites inflatus has not been recorded, although this could be due to its inconsistent presence in the lower meter of the "Glauconie grossière", as observed in the Gisors (no records in the lowermost $\mathrm{m}$ ) and the Margival outcrops (first occurrence at
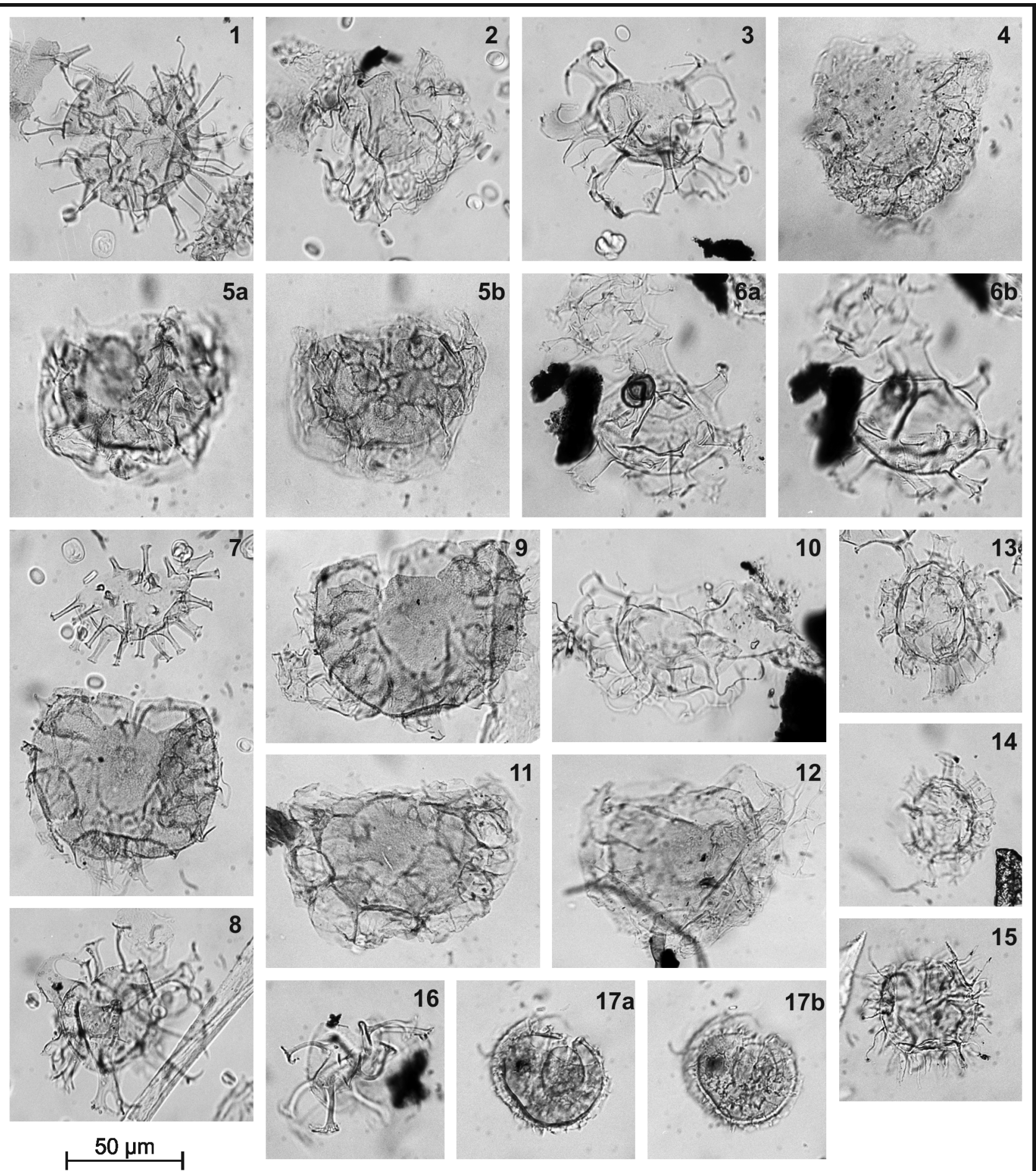

Figure 3. Organic-walled microfossil taxa from the Prémontré Sands (samples 1 and 8) and the "Glauconie grossière" (sample 14) at the Prémontré locality. A, B and C refer to the different micropalaeontologic slides; $\mathrm{a}$ and $\mathrm{b}$ to different views of the same specimen. $1=$ ? Cleistosphaeridium polypetellum, 14-A. 2 = Glaphyrocysta aff. exuberans, 14-B. 3 = Glaphyrocysta laciniiformis, 14-C. 4 = Glaphyrocysta reticulosa, 14-C. 5a,b = Glaphyrocysta sp. [cf. G.? undulata - G.? vicina], 1-C, a: high focus, b: low focus. 6a,b = Homotryblium oceanicum, 1-B, a: high focus, b: low focus $7=$ Polysphaeridium zoharyi (upper) and Areoligera tauloma (lower), 14-A. $8=$ Adnatosphaeridium vittatum, 14-B. $9=$ Areoligera tauloma, $14-$ A. $10=$ Adnatosphaeridium robustum, 8-C. $11=$ Glaphyrocysta $\mathrm{sp}$. [cf. G. ? undulata - G.? vicina], 14-A. $12=$ Glaphyrocysta $?$ spineta, $14-\mathrm{A} .13=$ Homotryblium abbreviatum, 14-C. $14=$ Homotryblium abbreviatum, 14-B. $15=$ Areoligera senonensis, 8-A. $16=$ Areosphaeridium diktyoplokum, 1-A. $17 \mathrm{a}, \mathrm{b}=$ Ochetodinium romanum, 14-B, a: high focus, b: low focus. 


\begin{tabular}{|c|c|c|c|}
\hline \multirow{2}{*}{ Organic-walled microfossils from the Prémontré Sands at Prémontré } & \multicolumn{3}{|c|}{ Samples } \\
\hline & 1 & 8 & 14 \\
\hline Chlorophyceae & & & \\
\hline Paralecaniella indentata (DEFLANDRE \& COOKSON, 1955) & $x$ & $x$ & $x$ \\
\hline Pediastrum sp. & $x x$ & $\hat{x}$ & $\mathrm{x}$ \\
\hline Dinophyceae & & & \\
\hline Achilleodinium sp. indet. & - & $\mathrm{x}$ & $\mathrm{x}$ \\
\hline Achomosphaera alcicornu (EISENACK, 1954) & - & - & $\mathrm{x}$ \\
\hline Achomosphaera spp. indet. & - & $\mathrm{x}$ & - \\
\hline Adnatosphaeridium multispinosum WILLIAMS \& DOWNIE, 1966 & $\mathrm{x}$ & $\mathrm{x}$ & $\mathrm{x}$ \\
\hline Adnatosphaeridium multispinosum ? WILLIAMS \& DOWNIE, 1966 & $\mathrm{x}$ & - & - \\
\hline Adnatosphaeridium robustum (MORGENROTH, 1966) & - & $\underline{\mathbf{x}}$ & $\mathrm{x}$ \\
\hline Adnatosphaeridium vittatum WILLIAMS \& DOWNIE, 1966 & $\mathrm{x}$ & $\overline{-}$ & $\underline{\mathbf{x}}$ \\
\hline Apectodinium parvum (ALBERTI, 1961) & - & $\mathrm{x}$ & $\overline{-}$ \\
\hline Areoligera senonensis LEJEUNE-CARPENTIER, 1938 & $\mathrm{x}$ & $\mathbf{x}$ & $\mathrm{x}$ \\
\hline ? Areoligera sentosa EATON, 1976 & $\mathrm{x}$ & $\overline{-}$ & - \\
\hline Areoligera tauloma EATON, 1976 & - & - & $\underline{\mathbf{x}}$ \\
\hline Areoligera sp. [cf. A. coronata (WETZEL, 1933) A. medusettiformis (WETZEL, 1933)] & - & $\mathrm{x}$ & $\overline{-}$ \\
\hline Areoligera sp. [cf. A. coronata (WETZEL, 1933) - A. senonensis LEJEUNE-CARPENTIER, 1938] & $\mathrm{x}$ & - & - \\
\hline Areoligera sp. [cf. Glaphyrocysta divaricata (WILLIAMS \& DOWNIE, 1966)] & $\mathrm{x}$ & $\mathrm{x}$ & - \\
\hline Areosphaeridium diktyoplokum (KLUMPP, 1953) & $\underline{\mathbf{x}}$ & - & $\mathrm{x}$ \\
\hline Cleistosphaeridium placacanthum ? (DEFLANDRE \& COOKSON, 1955) & $\overline{-}$ & $\mathrm{x}$ & $\mathrm{x}$ \\
\hline ? Cleistosphaeridium polypetellum (ISLAM, 1983) & - & - & $\underline{\mathbf{x}}$ \\
\hline Cordosphaeridium gracile (EISENACK, 1954) & $\mathrm{x}$ & $\mathrm{x}$ & $\overline{\mathrm{x}}$ \\
\hline Deflandrea phosphoritica EISENACK, 1938 & - & - & $\mathrm{x}$ \\
\hline Diphyes colligerum (DEFLANDRE \& COOKSON, 1955) & $\mathrm{x}$ & - & - \\
\hline Fibrocysta aff. radiata (MORGENROTH, 1966) & - & - & $\mathrm{x}$ \\
\hline Glaphyrocysta divaricata (WILLIAMS \& DOWNIE, 1966) & $\mathrm{x}$ & $\mathrm{x}$ & $\mathrm{x}$ \\
\hline Glaphyrocysta aff. exuberans (DEFLANDRE \& COOKSON, 1955) sensu EATON, 1976 & - & - & $\underline{\mathbf{x}}$ \\
\hline Glaphyrocysta laciniiformis (GERLACH, 1961) & - & - & $\underline{\bar{x}}$ \\
\hline ? Glaphyrocysta laciniiformis (GERLACH, 1961) & - & - & $\bar{x}$ \\
\hline Glaphyrocysta pasie/sii (DEFLANDRE \& COOKSON, 1955) & - & - & $\mathrm{x}$ \\
\hline Glaphyrocysta reticulosa (GERLACH, 1961) & - & - & $\underline{\mathbf{x}}$ \\
\hline Glaphyrocysta retiintexta (COOKSON, 1965) & $\mathrm{x}$ & - & $\overline{-}$ \\
\hline Glaphyrocysta? spineta (EATON, 1976) & - & - & $\underline{\mathbf{x}}$ \\
\hline Glaphyrocysta sp. [cf. G. divaricata - G. ordinate (WILLIAMS \& DOWNIE, 1966)] & $\mathrm{x}$ & - & - \\
\hline Glaphyrocysta sp. [cf. G. microfenestrata (BUJAK, 1976)] & $\mathrm{x}$ & - & - \\
\hline Glaphyrocysta sp. [cf. G. ? undulata EATON, 1976 - G. ? vicina EATON, 1976] & $\underline{\mathbf{x}}$ & $\mathrm{x}$ & $\underline{\mathbf{x}}$ \\
\hline Homotryblium abbreviatum EATON, 1976 & $\bar{x}$ & - & $\underline{\bar{x}}$ \\
\hline Homotryblium oceanicum EATON, 1976 & $\mathbf{x}$ & $\mathrm{x}$ & - \\
\hline Homotryblium tenuispinosum DAVEY \& WILLIAMS, 1966 & $\bar{x}$ & - & - \\
\hline Homotryblium spp. indet. & $\mathrm{x}$ & $\mathrm{x}$ & $\mathrm{x}$ \\
\hline Hystrichokolpoma granulatum EATON, 1976 & $\mathrm{x}$ & - & - \\
\hline ? Hystrichosphaeridium tubiferum (EHRENBERG, 1838) & $\mathrm{x}$ & - & - \\
\hline Hystrichosphaeridium ? sp. [cf. Homotryblium abbreviatum EATON, 1976] & - & $\mathrm{x}$ & $\mathrm{x}$ \\
\hline Impletosphaeridium cracens EATON, 1976 & $\mathrm{x}$ & - & - \\
\hline Impletosphaeridium ligospinosum (DE CONINCK, 1969) & - & - & $\mathrm{x}$ \\
\hline Lingulodinium machaerophorum (DEFLANDRE \& COOKSON, 1955) & - & $\mathrm{x}$ & - \\
\hline ? Membranophoridium perforatum WILSON, 1988 & $\mathrm{x}$ & $\mathrm{x}$ & - \\
\hline Ochetodinium romanum DAMASSA, 1979 & - & - & $\underline{\mathbf{x}}$ \\
\hline Pentadinium laticinctum GERLACH, 1961 & - & - & $\bar{x}$ \\
\hline Pentadinium? sp. [cf. P.? circumsutum (MORGENROTH, 1966)] & $\mathrm{x}$ & - & - \\
\hline Polysphaeridium zoharyi (ROSSIGNOL, 1962) & $\mathrm{x}$ & $\mathrm{x}$ & $\mathbf{x x}$ \\
\hline Samlandia chlamydophora EISENACK, 1954 & $\mathrm{x}$ & - & $\bar{x}$ \\
\hline Spiniferites adnatus? MATSUOKA \& BUJAK, 1988 & $\mathrm{x}$ & - & $\mathrm{x}$ \\
\hline Spiniferites sp. [aff. Achomosphaera crassipellis (DEFLANDRE \& COOKSON, 1955)] & - & - & $\mathrm{x}$ \\
\hline Spiniferites spp. indet. & $\mathrm{x}$ & - & $\mathrm{x}$ \\
\hline Thalassiphora patula? (WILLIAMS \& DOWNIE, 1966) & $\mathrm{x}$ & - & $\mathrm{x}$ \\
\hline Thalassiphora pelagica (EISENACK, 1954) & - & - & $\mathrm{x}$ \\
\hline Wetzeliella sp. indet. & - & - & $\mathrm{x}$ \\
\hline Prasinophyceae & & & \\
\hline Pterospermella barbarae (GORKA, 1964) & - & - & $\mathrm{x}$ \\
\hline Pterospermella ginginensis (DEFLANDRE \& COOKSON, 1955) & - & - & $\mathrm{x}$ \\
\hline
\end{tabular}

Table 1. List of the organic-walled microfossil taxa recorded in the Prémontré outcrop. Numbers refer to sample positions (1 and $8=$ Prémontré Sands; $14=$ "Glauconie grossière"). Data in bold (and underlined in case of the abundance symbols) refer to taxa illustrated in Fig. 3. The relative abundance of the taxa is indicated by the following symbols: $\mathrm{x}=$ present; $\mathrm{X}=$ frequent, $\mathrm{XX}=$ abundant.

about $2.5 \mathrm{~m}$ above the base, although very rarely) respectively $122 \mathrm{~km}$ west and $12.5 \mathrm{~km}$ south of Prémontré (Steurbaut, 1988).

The presence of D. sublodoensis indicates that the base of the "Glauconie grossière" belongs to Martini's (1971) calcareous nannofossil zone NP14; the apparent absence of $B$. inflatus does not allow its further subdivision.

\subsection{Organic-walled microfossil diversity and biozonation}

The organic-walled microfossil assemblages of the Prémontré Sands (samples 1 and 8) are poorly preserved and show moderate diversity (39 taxa, among which 37 are dinoflagellate taxa, see Table 1 and Fig. 3). They are dominated by the freshwater algal taxon Pediastrum sp., which is extremely abundant at its base, and somewhat lesser higher up. High numbers of the dinoflagellate cyst Polysphaeridium zoharyi are recorded in the upper sample, while Wetzelielloideae are virtually absent throughout the unit (1 specimen of Apectodinium parvum in the upper sample). Among the stratigraphic relevant dinoflagellate cyst taxa are Areosphaeridium diktyoplokum (lowermost sample), Areoligera senonensis (throughout the unit), ?Areoligera sentosa (lowermost sample), Homotryblium abbreviatum (lowermost sample) and $H$. oceanicum (throughout the unit), Impletosphaeridium cracens (lowermost sample) and ?Membranophoridium perforatum (throughout the unit). The assemblages are furthermore characterised by the absences of Phthanoperidinium comatum and Areoligera tauloma. Because of the presence of A. diktyoplokum and the absence of Enneadocysta pectiniformis the Prémontré Sands are classified in the D9 dinoflagellate cyst Zone of Costa \& Manum (1988), which is long-ranging from early late Ypresian to top of the Lutetian (50.5 Ma - 40.4 Ma, according to Köthe, 2012). Köthe's refined dinoflagellate cyst zonation, covering the eastern North Sea Basin, cannot be applied here because of the poor preservation and the moderate diversity of the assemblages, resulting in the absence of Köthe's subzonal markers. Correlation of the Prémontré Sands with the upper part of the Wittering Formation in southern England is based on the co-occurrence of A. diktyoplokum and I. cracens, and the absence of $A$. tauloma, referring to the lower part of the Phthanoperidinium comatum Assemblage Zone (B-3), as defined in Bujak et al. (1980) (see also Islam, 1983). However, this zonal attribution is not in line with the data recorded in the Belgian Basin (Steurbaut \& Van Simaeys, unpublished information; see discussion below).

The base of the "Glauconie grossière" (sample 14, Table 1) also yields a poorly preserved low to moderate-diversity dinoflagellate cyst assemblage (34 taxa), dominated by $P$. zoharyi. The freshwater alga Pediastrum sp. is very rare. Wetzeliellaceae are also virtually absent (1 specimen of an unidentifiable Wetzeliella species). The assemblage is furthermore marked by the presence of A. diktyoplokum, 
A. tauloma and Impletosphaeridium ligospinosum, and consequently also attributable to dinoflagellate zone D9, ranging from early late Ypresian to top Lutetian. The presence of $A$. tauloma, in association with the absence of the markers of the Areosphaeridium arcuatum Assemblage Zone or Zone B-4 of Bujak et al., 1980 (e.g. Enneadocysta arcuata -formerly Areosphaeridium arcuatum-, Fibrocysta vectensis and Turbiosphaera magnifica; see also King, 2016, p. 407), suggests its attribution to the upper part of Zone B-3, which in S England covers the lower and middle part of the Earnley Formation (King, op. cit.).

\subsection{Palaeoenvironmental analysis of the organic-walled micro- fossil assemblages}

The poor palynological content of the Prémontré Sands, marked by low numbers of pollen and spores and by poorly preserved dinoflagellate cyst assemblages seems to point to moderate to considerable oxidation of the sediment, although it is not clear if these phenomena happened at the time of deposition or are post-depositional. Whatever its origin, this poor preservation may have caused a decline in dinoflagellate cyst diversity, and hindered precise identification of numerous taxa. The overall composition of the dinoflagellate cyst assemblages indicates a marine palaeoenvironment (presence of Spiniferites spp., Thalassiphora spp., Samlandia chlamydophora, etc.), although probably shallow to marginal (high diversity of Homotryblium, frequent Polysphaeridium zoharyi) (Dybkjær, 2004; Sluijs et al., 2005), with substantial influx of freshwater elements (dominance of Pediastrum sp., a freshwater green algal taxon that today is frequently occurring in ponds and lakes of temperate and warm regions; see Zamaloa \& Tell, 2005 for its (palaeo)environmental significance). The frequence of $P$. zoharyi refers to a tropical to subtropical climate. There are considerable differences in species diversity and in species frequencies throughout the Prémontré Sands. Of the 37 taxa only 10 are in common in the two samples, among which? Membranophoridium perforatum, H. oceanicum and Areoligera sp. [cf. Glaphyrocysta divaricata] are not found higher up in the "Glauconie grossière". The richest assemblage is recorded at the base of the Prémontré Sands, counting 29 taxa and dominated by the green alga Pediastrum sp. Higher up species diversity (19 taxa) and Pediastrum numbers substantially decrease, although the latter still occurring frequently, while the Spiniferites taxa and most of the Glaphyrocysta taxa are no longer present. This, in association with the substantial increase in Polysphaeridium zoharyi, indicates a diminishing of the freshwater influx higher up in the Prémontré Sands and the development of bays or lagoons, with occasional salinity fluctuations.

The abundance of Polysphaeridium zoharyi, the low numbers of Pediastrum sp. and the high taxonomic diversity of Glaphyrocysta (6 taxa) at the base of the "Glauconie grossière" refer to an inner neritic well-protected bay-like environment in which hypersaline conditions prevailed (palaeoenvironmental interpretation based on Sluijs et al., 2005).

\section{Discussion}

\subsection{Depositional conditions of the Prémontré Sands}

At their type-locality the Prémontré Sands are marked by a fully marine ray and shark fauna, essentially littoral, although including forms which frequent open seas (Adnet \& Cappetta, 2008), and by several sets of cross and horizontally stratified fine sands, which are slightly glauconitic and rich in coarse quartz grains and flint fragments. These characteristics, which are well developed in the early phase of the deposition of these sands, reflect a high-energy depositional regime, with frequent periods of winnowing and redistribution of sediment, indicating an open estuarine setting. This shallow to marginal marine setting is corroborated by the presence of littoral teleost fishes (Labridae, Scaridae, etc.) and the marine to marginal marine dinoflagellate cyst assemblage. The influx of freshwater algae (Pediastrum) and plant debris are probably due to storm surges, flooding and eroding adjacent soils, lakes or marshes, through which their remnants entered the estuarine deposition system. The presence of terrestrial vertebrates, such as lizards, snakes, and mammals, and freshwater vertebrates, like Amia and Lepisosteus, frogs and crocodiles can be explained in the same way.

These high energy conditions seemed to fade away not only during the final phase of sedimentation of these sands, but also laterally, as within a $300 \mathrm{~m}$ range in northeasterly direction there was a progressive increase in marl and clay beds, towards an almost exclusive clayey, low energy depositional regime (Laon Clay-type), indicating a bay-like to lagoonal environment. This is in line with the increase of Polysphaeridium zoharyi up-section.

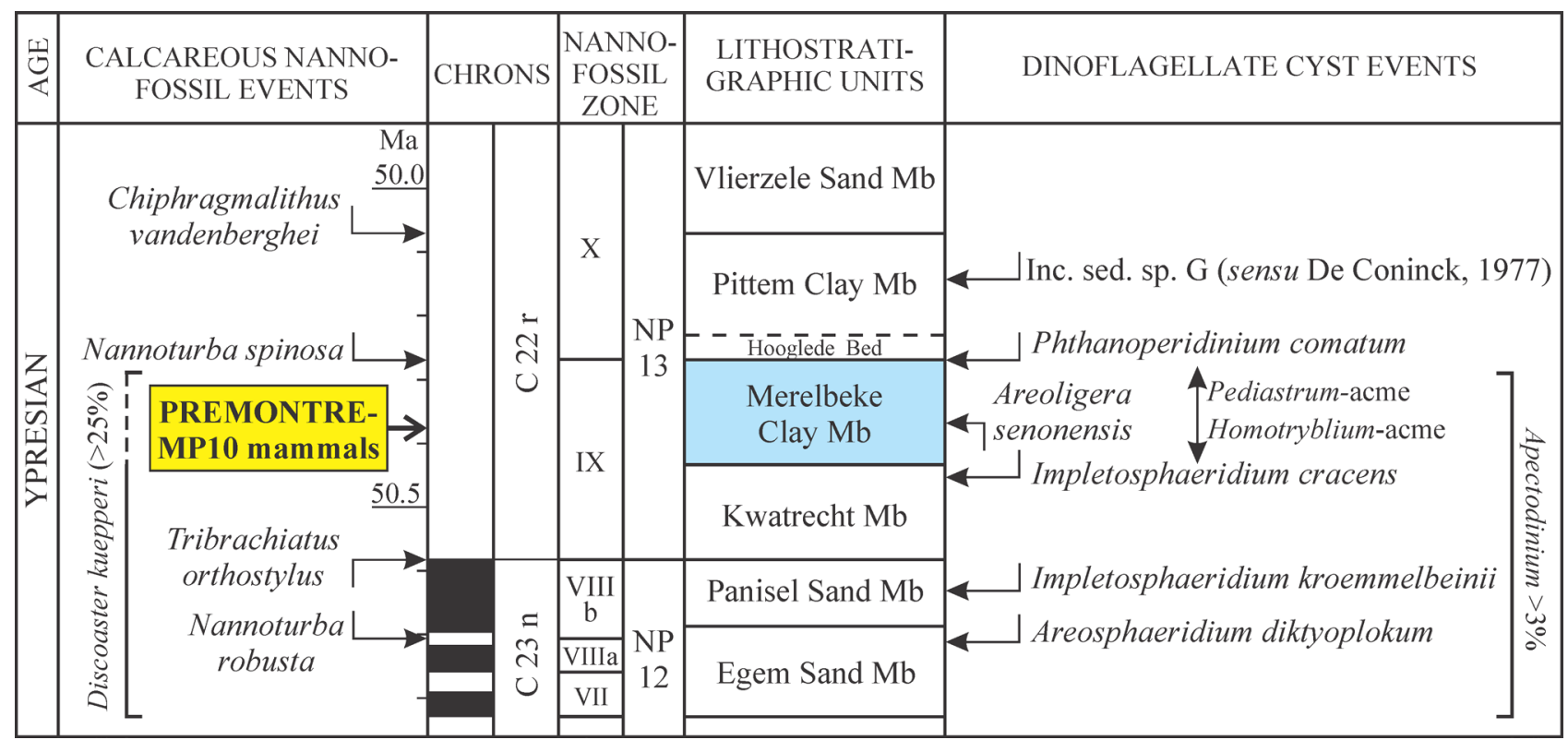

Figure 4. Integrated high resolution stratigraphy of the lower part of the upper Ypresian of Belgium with dinoflagellate cyst-based positioning of the Prémontré MP 10 mammal fauna (calcareous nannofossil data based on Steurbaut, 1998 and 2011; dinoflagellate cyst data on De Coninck, 1977, Steurbaut et al., 2015 and Steurbaut \& Van Simaeys, unpublished information) (the interrupted line indicates that the Merelbeke Clay is not calcareous, but that high frequencies of D. kuepperi ( 15-20\%) have been recorded in samples just above the Merelbeke Clay, in a still unnamed unit, Steurbaut, unpublished information). 


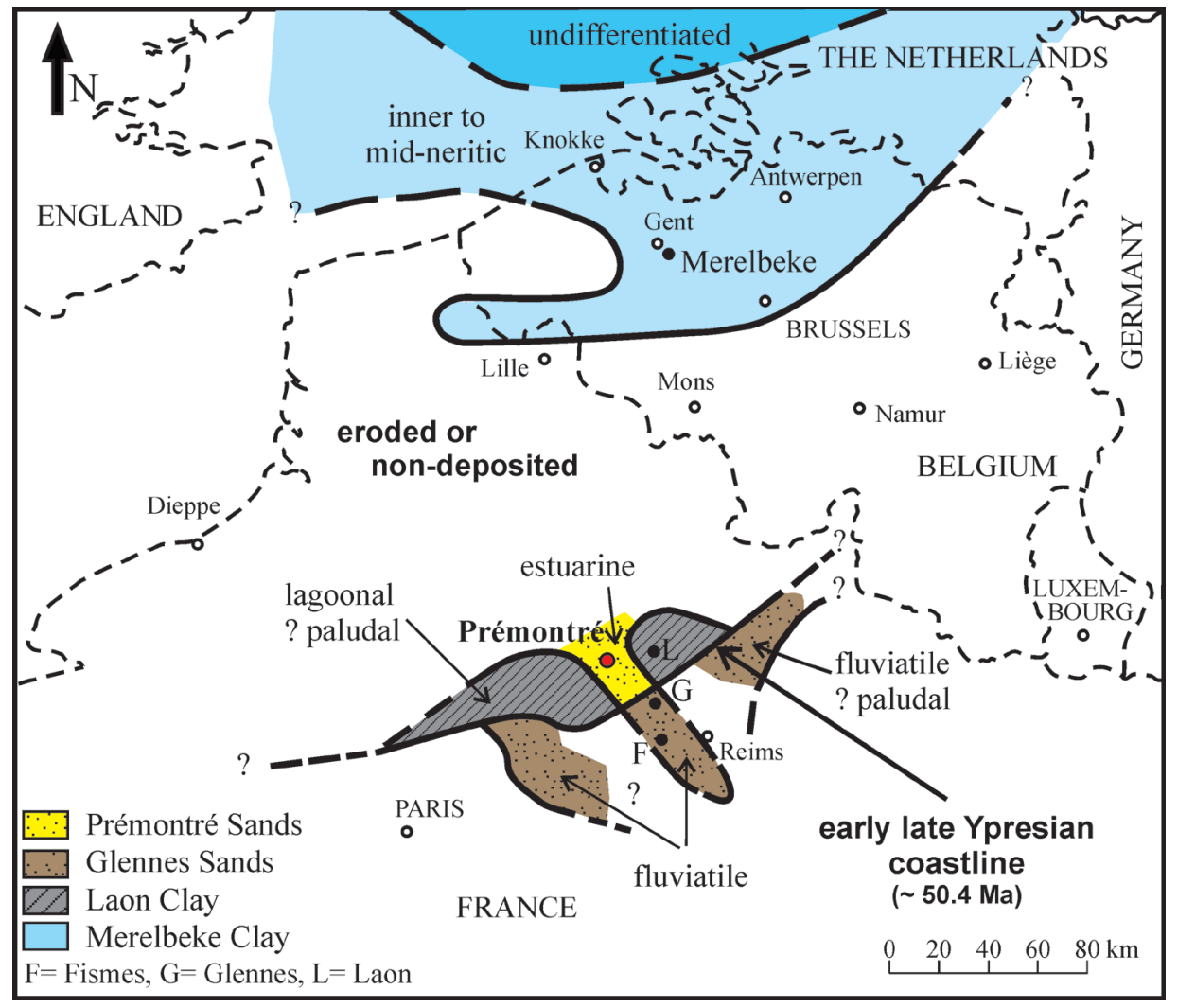

Figure 5. Generalised palaeogeography and lithofacies distribution in the southern North Sea Basin and Paris Basin at ca 50.4 Ma (early Chron C22r, early late Ypresian), after Steurbaut (unpublished information) for the Belgian data, and Leriche (1937) and Feugueur (1963) for the Paris Basin.

\subsection{The age of the Prémontré mammal fauna}

The upper Ypresian dinoflagellate cyst succession in Belgium is by far the most complete of the southern North Sea Basin, because all recognized lithofacies, ranging from sand banks through shoreface sands to inner neritic clays (Steurbaut, 2006), contain moderately to well preserved and highly diversified dinoflagellate cyst assemblages. The Belgian data (Steurbaut \& Van Simaeys, unpublished information) reveal that Samlandia chlamydophora, Charlesdowniea columna (group)/Glaphyrocysta spineta, Areosphaeridium diktyoplokum, Impletosphaeridium kroemmelbeinii, cf. Areoligera sentosa, Impletosphaeridium cracens, Phthanoperidinium comatum, Enneadocysta arcuata and Areoligera tauloma constitute a chronological sequence of appearances within the upper Ypresian (upper NP12 - upper NP 13), with A. tauloma as youngest member. A more or less similar sequence of events has been identified at Whitecliff Bay (Eaton, 1976), Alum Bay (Eaton, 1976) and Bracklesham Bay (Islam, 1983) in S. England, and in the Wursterheide borehole in NW Germany (Heilmann-Clausen \& Costa, 1989), although not the entire suite and often with striking differences. At Whitecliff Bay and Alum Bay I. cracens and P. comatum appear simultaneously in the stratigraphic record, whereas at Bracklesham Bay, the first occurrence of $P$. comatum predates the first occurrence of I. cracens. The same is true for I. kroemmelbeinii and $A$. tauloma, which appear simultaneously at Whitecliff Bay and Alum Bay, but of which the first occurrences do not coincide at Bracklesham Bay, A. tauloma appearing later. A. diktyoplokum, cf. A. sentosa, P. comatum and A. tauloma appear in chronological order in the Wursterheide borehole (Heilmann-Clausen \& Costa, 1989), similar to what has been observed in Belgium. However, the main difference is that $I$. kroemmelbeinii and I. cracens have not been identified in the Wursterheide borehole, and, that in that section, as well as in the English sections mentioned above, E. arcuata appears later in the fossil record than A. tauloma. The Belgian succession indicates that the order of occurrences in all English sections, but especially at Alum Bay and Bracklesham Bay, is biased by intervening non-marine strata or non-productive lithologies (presence of barren sands), resulting in the delayed first occurrence of several taxa.
The presence of $A$. diktyoplokum, $A$. senonensis and I. cracens, in association with the absence of $P$. comatum, the abundance of Pediastrum spp. and the high diversity in Homotryblium spp. suggest a close correlation between the Prémontré Sands and the Merelbeke Clay in Belgium, which has been accurately dated (Fig. 4). The Merelbeke Clay Member has recently been attributed to lower NP13 and early Chron C22r (Steurbaut et al., 2015). This clay unit falls within an interval dominated by Discoaster kuepperi $(>25 \%)$ and is furthermore marked by relatively low values in $\delta^{13}$ Corg and relatively high values of Apectodinium (>3\%), assumed to indicate deposition during the final phase of the Early Eocene Climatic Optimum (EECO) (Steurbaut et al., 2015). The deposition of the MP10 Prémontré mammal fauna is estimated to postdate the onset of both NP13 and Chron C22r, which nearly coincide, by about 200 to $300 \mathrm{kyr}$, and thus took place around 50.4 to 50.3 million years ago. Note that the base of C22r and the NP12/NP13 boundary are virtually coincident in the North Sea Basin (data from Albaekhoved, Denmark, Steurbaut, 1998 and from hole 81/46A off Yorkshire, Steurbaut, unpublished information), but are a little offset in Italy (? $100 \mathrm{kyr})$, the NP12/NP13 boundary slightly postdating the base of Chron C22r (Agnini et al., 2006, adopted in Vandenberghe et al., 2012). The correlation with the Merelbeke Clay Member also indicates that the Prémontré Sands were deposited following a major sea-level rise, the highest in the southern North Sea Basin s.l. (including the Paris Basin) during late Ypresian times (Fig. 5). Their deposition represents the highstand systems tract of depositional sequence Y-I of Steurbaut (2015).

\section{Conclusions}

The key conclusions that emerge from this integrated calcareous nannofossil and dinoflagellate cyst investigation are:

1. The Prémontré Sands underwent a gradual transition from estuarine to lagoonal depositional regime at their type locality, up-section as well as laterally, as shown by their lithofacies characteristics and their organic-walled microfossil assemblages. They are probably coeval with the Glennes Sands, which are believed to represent their lateral fluviatile equivalent. 
2. The dinoflagellate cyst data (co-occurrence of $A$. diktyoplokum, A. senonensis and I. cracens; absence of $P$. comatum) indicate direct correlation between the Prémontré Sands and the well-dated Merelbeke Clay Member in Belgium, allowing their attribution to the lower part of calcareous nannofossil zone NP13 and the early part of Chron C22r. It is estimated that the deposition of the Prémontré mammal fauna postdates the onset of both NP13 and Chron C22r, which are almost coincident, by about 200 to $300 \mathrm{kyr}$, and thus took place around 50.4 to 50.3 million years ago. This correlation also implies that the MP10 Prémontré mammal fauna fossilised during the final phase of the EECO.

3. At their type locality the Prémontré Sands are bounded by major hiatuses, viz., one at the base with a duration of about 2.2 myr with the underlying sands, if it is undoubtedly proved that these correspond to the Pierrefonds Sands (the top of the latter is attributed to the basal part of NP12 and to subzone IIIb of Steurbaut (1988), currently dated at $~ 52.6$ $\mathrm{Ma}$ ), and another hiatus at the top, of about 2.5 myr with the overlying "Glauconie grossière".

\section{Taxonomic remarks}

The organic-walled microfossils identified in the scope of this study are alphabetically listed in Table 1. Additional information is given for the taxa treated in open nomenclature, when necessary, and put inside brackets [...].

\section{? Membranophoridium perforatum Wilson, 1988}

The specimens from the Prémontré Sands are very similar to the type material from the upper Ypresian of New Zealand (Wilson, 1988). They also present strong affinities with Glaphyrocysta vicina (Eaton, 1976) from the Bracklesham Group in S England. It is also quite possible that the Prémontré material is identical to that described as Chiropteridium aspinatum (Gerlach, 1961) (now Membranophoridium aspinatum Gerlach, 1961) from the "Argile de Laon" in the Paris Basin (Gruas-Cavagnetto, 1976).

\section{Acknowledgements}

The authors are much obliged to Henri Cappetta (Université de Montpellier II, France) for having provided the samples from the Prémontré outcrop. They are grateful to Thierry Hubin (RBINS) for assistance given in photographic work and to Adriano Vandersypen (RBINS) for help in production of the figures. Dr. Claus Heilmann-Clausen (Aarhus Universitet, Denmark) and Dr. Jerry Hooker (Natural History Museum, UK) are thanked for reviews improving the manuscript.

\section{References}

Adnet, S. \& Cappetta, H., 2008. New fossil triakid sharks from the early Eocene of Prémontré, France, and comments on fossil record of the family. Acta Palaeontologica Polonica, 53/3, 433-448.

Agnini, C., Muttoni, G., Kent, D.V. \& Rio, D., 2006. Eocene biostratigraphy and magnetic stratigraphy from Possagno, Italy: The calcareous nannofossil response to climate variability. Earth and Planetary Science Letters, 241, 815-830.

Aubry, M.-P. \& Bord, D., 2009. Reshuffling the cards in the photic zone at the Eocene/Oligocene boundary. In Koeberl, C. \& Montanari, A. (eds), The Late Eocene Earth. Geological Society of America Special Paper, 452, 279-301.

Augé, M., 2003. La faune de Lacertilia (Reptilia, Squamata) de l'Eocène inférieur de Prémontré (Bassin de Paris, France). Geodiversitas, 25/3, 539-574.

Augé, M., Duffaud, S., de Lapparant de Broin, F., Rage, J.-C. \& Vasse, D., 1997. Les amphibiens et les reptiles de Prémontré (Cuisien, Bassin parisien): une herpétofaune de référence pour l'Eocène inférieur. Géologie de la France, 1, 23-33.

Blanc-Louvel, C., 1986. Paléoflore du gisement Eocène de Prémontré dans l'Aisne: Vitaceae. 111ème Congrès National des Sociétés Savantes, Poitiers, 2, 37-48

Blondeau, A., 1981. Lutetian. In Pomerol, Ch. (ed.), Stratotypes of Paleogene stages. Bulletin d'Information des Géologues du Bassin de Paris, Mémoire Hors Série 2, 167-180.
Bujak, J.P., Downie, C., Eaton, G.L.\& Williams, G.L., 1980. Dinoflagellate cyst zonation of the Eocene, southern England. In Bujak, J.P., Downie, C., Eaton, G.L. \& Williams, G.L. (eds), Dinoflagellate cysts and acritarchs from the Eocene of southern England. Special Papers in Palaeontology, 24, 15-26.

Cappetta, H., 1992. Carcharhiniformes nouveaux (Chondrichthyes, Neoselachii) de 1'Yprésien du Bassin de Paris. Geobios, 25/5, 639646.

Costa, L.I. \& Manum, S.B., 1988. The description of the interregional zonation of the Paleogene (D1-D15) and the Miocene (D16-D20) In Vinken, R. (ed.), The Northwest European Tertiary Basin. Geologisches Jahrbuch, A, 100, 321-332.

De Coninck, J., 1977. Organic walled microfossils from the Eocene of the Woensdrecht borehole, southern Netherlands. Mededelingen Rijks Geologische Dienst, N.S. 28/3, 33-64.

Dégremont, E., Duchaussois, F., Hautefeuille, F., Laurain, M., Louis, P. \& Tétu, R., 1985. Paléontologie: Découverte d'un gisement du Cuisien tardif à Prémontré (Aisne). Bulletin d'Information des Géologues du Bassin de Paris, 22/2, 11-18.

Delattre, Ch., Mériaux, E. \& Waterlot, M., 1973. Région du Nord (Flandre, Artois, Boulonnais, Picardie). Masson, Paris. Guides géologiques régionaux. $176 \mathrm{p}$.

Duprat, M., 1997a. Modèle tectono-sédimentaire des dépôts paléogènes dans le Nord-Est du Bassin de Paris: conséquences sur la géométrie du toit de la Craie. Annales de la Société Géologique du Nord, $2^{\mathrm{e}}$ sér., $5,269-287$

Duprat, M., 1997b. Les faciès à mammifères (MP 6 à MP 16) dans le Nord-Est du Bassin de Paris (France): argumentation du modèle tectono-sédimentaire des dépôts paléogènes. Actes du Congrès BiochroM'97, Montpellier, 14-17 Avril. Mémoires et Travaux de l'Institut de Montpellier, 21, 315-336.

Dybkjær, K., 2004. Morphological and abundance variations in Homotryblium-cyst assemblages related to depositional environments; uppermost Oligocene-Lower Miocene, Jylland, Denmark. Palaeogeography, Palaeoclimatology, Palaeoecology, 206/1-2, 41-58.

Eaton, G.L., 1976. Dinoflagellate cysts from the Bracklesham Beds (Eocene) of the Isle of Wight, southern England. Bulletin of the British Museum (Natural History). Geology, 26/6, 227-332.

Escarguel, G., 1999. Les Rongeurs de l'Eocène inférieur et moyen d'Europe occidentale. Systématique, phylogénie, biochronologie et paléobiogéographie des niveaux-répères MP 7 à MP 14 . Palaeovertebrata, 28/2-4, 89-351.

Feugueur, L., 1963. L'Yprésien du Bassin de Paris - Essai de monographie stratigraphique. Mémoires pour servir à l'explication de la Carte géologique détaillée de la France, 568 p.

Gély, J.-P., 1996. Le Lutétien du Bassin de Paris : de l'analyse séquentielle haute-résolution à la reconstitution paléogéographique. Bulletin d'Information des Géologues du Bassin de Paris, 34/2, 3-27.

Gély, J.-P., 2009. Le Lutétien: une période charnière de l'histoire du Bassin de Paris. Saga Information, 284, 6-24.

Gély, J.-P. \& Lorenz, C., 1991. Analyse séquentielle de l'Eocène et de l'Oligocène du Bassin parisien (France). Revue de l'Institut français du Pétrole, 46/6, 713-747.

Godinot, M. (coord.), 1987. Mammalian Reference Levels MP 1-10. In Schmidt-Kittler, N. (ed.), International Symposium on Mammalian Biostratigraphy and Paleoecology of the European Paleogene Mainz, February 18th-21st 1987. Münchner Geowissenschaftliche Abhandlungen, A, 10, 21-23.

Godinot, M., Russell, D.E. \& Louis, P., 1992. Oldest known Nannopithex (Primates, Omomyiformes) from the early Eocene of France. Folia Primatologia, 58, 32-40.

Gruas-Cavagnetto, C., 1976. Les marqueurs stratigraphiques (dinoflagellés) de l'Éocène du bassin de Paris et de la Manche orientale. Revue de Micropaléontologie, 18/4, 221-228.

Heilmann-Clausen, C. \& Costa, L.I., 1989. Dinoflagellate Zonation of the Uppermost Paleocene? to Lower Miocene in the Wursterheide Research Well, NW Germany. Geologisches Jahrbuch, A, 111, 431521.

Hooker, J.J., 1996. Mammals from the Early (late Ypresian) to Middle (Lutetian) Eocene Bracklesham Group, southern England. Tertiary Research, 16/1-4, 141-174.

Islam, M.A., 1983. Dinoflagellate cyst taxonomy and biostratigraphy of the Eocene Bracklesham Group in southern England Micropaleontology, 29/3, 328-353.

King, C., 2016. A Revised Correlation of Tertiary Rocks in the British Isles and adjacent areas of NW Europe. Geological Society Special Report, 27, $719 \mathrm{p}$.

Köthe, A., 2012. A revised Cenozoic dinoflagellate cyst and calcareous nannoplankton zonation for the German sector of the southern North Sea Basin. Newsletters on Stratigraphy, 45/3, 189-220. 
Leriche, M., 1912. Excursion du vendredi 30 août, à Montbérault, Monthenault, Chamouille, Paissy, Pargnan, Beaurieux, Glennes, Merval et Fismes. Bulletin de la Société Géologique de France, $4^{\mathrm{e}}$ sér., 12, 743-754.

Leriche, M., 1937. Les rapports entre les formations tertiaires du bassin belge et du bassin de Paris. Bulletin de la Société Belge de Géologie, de Paléontologie et d'Hydrologie, 47, 552-655.

Louis, P., 1996. Recherches de mammifères paléogènes dans les départements de l'Aisne et de la Marne pendant la deuxième moitié du vingtième siècle. In Godinot, M. \& Gingerich, P.D. (eds), Paléobiologie et évolution des mammifères du Paléogène - Volume jubilaire en hommage à Donald E. Russell. Palaeovertebrata, 25/2-4, 83-113.

Marivaux, L., Vianey-Liaud, M. \& Jaeger, J.J., 2004. High-level phylogeny of early Tertiary rodents: dental evidence. Zoological Journal of the Linnean Society, 142, 105-134.

Martini E., 1971. Standard Tertiary and Quaternary calcareous nannoplankton zonation. In Farinacci A. (ed.), Proceedings of the $2^{\text {nd }}$ Planktonic Conference (Roma, 1970). Technoscienza, Roma, 2, 739-785.

Merle, D. (ed.), 2008. Stratotype Lutétien. Collection Patrimoine géologique. Muséum national d'Histoire naturelle, Paris, Biotope, Mèze, BRGM, Orléans, 288 p.

Molina, E., Alegret, L., Apellaniz, E., Bernaola, ,G., Caballero, F., Dinarès-Turell, J., Hardenbol, J., Heilmann-Clausen, C., Larrasoaña, J.C., Luterbacher, H., Monechi, S., Ortiz, S., Orue-Etxebarria, X., Payros, A., Pujalte, V., Rodríguez-Tovar, F.J., Tori, F., Tosquella, J. \& Uchman, A., 2011. The Global Standard Stratotype Section and Point (GSSP) for the base of the Lutetian Stage at the Gorrondatxe section (Spain). Episodes, 34/2, 86-108.

Perch-Nielsen K., 1985. Cenozoic calcareous nannofossils. In Bolli, H.M., Saunders, J.B. \& Perch-Nielsen K. (eds), Plankton Stratigraphy. Cambridge University Press, Cambridge. Cambridge Earth Science Series, 11, 427-554.

Rat, P., 1965. La succession stratigraphique des mammifères dans l'Eocène du Bassin de Paris. Bulletin de la Société géologique de France, $7^{\mathrm{e}}$ sér., 7/2, 248-256.

Russell, D.A., 2009. Islands in the Cosmos: the evolution of life on land. Indiana University Press, Bloomington. Life of the Past Series, 480 p.

Russell, D.E., 1964. Les Mammifères paléocènes d'Europe. Mémoires du Musée national d'Histoire naturelle, C, Sciences de la Terre, 13, $324 \mathrm{p}$.

Schmidt-Kittler, N. (ed.), 1987. International Symposium on Mammalian Biostratigraphy and Paleoecology of the European Paleogene Mainz, February 18th-21st 1987. Münchner Geowissenschaftliche Abhandlungen, A, 10, $321 \mathrm{p}$.

Sluijs, A., Pross, J. \& Brinkhuis, H., 2005. From greenhouse to icehouse; organic-walled dinoflagellate cysts as paleoenvironmental indicators in the Paleogene. Earth-Science Reviews, 68, 281-315.

Smith, R., 2001. Les pantolestidés (Mammalia, Pantolesta) de 1'Eocène inférieur de Prémontré (Aisne, France). Palaeovertebrata, 30/1-2, 1135.

Smith, T. \& Smith, R., 2013. A land micro-mammal fauna from the Early Eocene marine Egem deposits (NP12, Belgium) and the first occurrence of the peradectid marsupial Armintodelphys outside North America. In Smith, T. \& Gunnell G.F. (eds), Dispersal of continental vertebrates during the Paleogene. Geologica Belgica, 16/4, 302-310.

Steurbaut, E., 1988. New Early and Middle Eocene calcareous nannoplankton events and correlations in middle to high latitudes of the northern hemisphere. Newsletters on Stratigraphy, 18/2, 99-115.

Steurbaut, E., 1998. High-resolution holostratigraphy of Middle Paleocene to Early Eocene strata of Belgium and adjacent areas. Palaeontographica, Abt. A, 247/5-6, 91-156.

Steurbaut, E., 2006. Ypresian. In Dejonghe, L. (ed.), Current status of chronostratigraphic units named from Belgium and adjacent areas. Geologica Belgica, 9/1-2, 73-93.

Steurbaut, E., 2011. New calcareous nannofossil taxa from the Ypresian (Early Eocene) of the North Sea Basin and the Turan Platform in West Kazakhstan. Bulletin de 1'Institut royal des Sciences naturelles de Belgique, Sciences de la Terre, 81, 247-277.

Steurbaut, E., 2015. Het Vroeg-Eoceen. In Borremans, M. (ed.), Geologie van Vlaanderen. Academia Press, Gent, 125-135.

Steurbaut, E. \& King, C., 1994. Integrated stratigraphy of the MontPanisel borehole section (151E340), Ypresian (Early Eocene) of the Mons Basin, SW Belgium. Bulletin van de Belgische Vereniging voor Geologie, 102/1-2 (1993), 175-202.

Steurbaut, E., King, C., Matthijs, J., Noiret, C., Yans, J. \& Van Simaeys, S., 2015. The Zemst borehole, first record of the EECO in the North Sea Basin and implications for Belgian Ypresian - Lutetian stratigraphy. Geologica Belgica, 18/2-4, 147-159.

Vandenberghe, N., Hilgen, F.J. \& Speijer, R.P., 2012. The Paleogene period. In Gradstein, F.M., Ogg, J.G., Schmitz, M. \& Ogg, G.M. (eds), The Geologic Time Scale 2012. Elsevier, Amsterdam, 855-921.
Wallach, V., Williams, K.L. \& Boundy, J., 2014. Snakes of the World: A Catalogue of Living and Extinct Species. CRC Press, Boca Raton, $1237 \mathrm{p}$.

Wilson, G.J., 1988. Paleocene and Eocene dinoflagellate cysts from Waipawa, Hawkes Bay, New Zealand. New Zealand Geological Survey Paleontological Bulletin, 57, 96 p.

Young, J.R. \& Bown, P.R., 1997. Cenozoic calcareous nannoplankton classification. Journal of Nannoplankton Research, 19/1, 38-56.

Zamaloa, M.C. \& Tell, G., 2005. The fossil record of freshwater microalgae Pediastrum Meyen (Chlorophyceae) in southern South America. Journal of Paleolimnology, 34/4, 433-444.
Manuscript received 24.02.2016, accepted in revised form 30.05.2016, available on line 01.08.2016. 